\title{
Ensefalopati Dengue pada Anak
}

\author{
Novie Homenta Rampengan, ${ }^{*}$ Mulya Rahma Karyanti, ${ }^{* *}$ Sri Rezeki Hadinegoro ${ }^{* *}$ \\ *Bagian Ilmu Kesehatan Anak FK UNSRAT/RSUP Prof. R.D. Kandou, Manado \\ **Departemen Ilmu Kesehatan Anak FK UI/RS Dr. Cipto Mangunkusumo, Jakarta
}

\begin{abstract}
Latar belakang. Infeksi virus dengue pada manusia mengakibatkan spektrum manifestasi klinis yang bervariasi. Ensefalopati dengue atau demam berdarah dengue (DBD) dengan keterlibatan susunan saraf pusat (SSP) merupakan kondisi yang jarang terjadi namun angka kematiannya cukup tinggi.

Tujuan. Mengetahui insiden, karakteristik demografik, manifestasi klinis, laboratorium dan luaran pasien dengan ensefalopati dengue.

Metode. Studi deskriptif retrospektif di RS Dr. Cipto Mangunkusumo (RSCM) Jakarta. Kriteria inklusi adalah rekam medik pasien yang dirawat di RSCM tahun 2006-2010 dengan diagnosis ensefalopati dengue.

Hasil. Terdapat 20 pasien (2,8\%) ensefalopati dengue dari 717 pasien infeksi virus dengue. Pasien terbanyak berusia 2-5 tahun ( 8 pasien) diikuti usia $>10$ tahun ( 7 pasien) dengan rerata usia 6,6 tahun. Kejadian DBD dengan syok terdapat pada 13 pasien, kejang pada 8 pasien, perdarahan saluran cerna pada 12 pasien dan rerata penurunan kesadaran pada hari ke 4,3 dengan lama 2,5 hari. Laboratorium didapatkan rerata natrium 131,6 meq/L, rerata SGOT/AST $2347 \mathrm{mg} / \mathrm{dl}$ dan rerata SGPT/ALT $630 \mathrm{mg} / \mathrm{dl}$. Terdapat pemanjangan PT dengan rerata 22,4” dan pemanjangan aPTT dengan rerata 86,2". Didapatkan infeksi sekunder dengue pada 18 pasien. Antimikroba diberikan pada 16 pasien sedangkan kortikosteroid pada 5 pasien. Ditemukan 3 pasien dengan gejala sisa berupa slurred speech, afasia dan tetraparesis serta 1 pasien meninggal.

Kesimpulan. Insiden ensefalopati dengue 2,8\% dengan infeksi sekunder dengue sebagai penyebab tersering, namun tidak terdapat perbedaan kelompok usia dibandingkan DBD. Terdapat peningkatan yang tinggi dari serum transaminase, pemanjangan PT/APTT, hiponatremia. Terdapat gejala sisa pada 3 dari 19 pasien yang hidup. Sari Pediatri 2011;12(6):419-25.
\end{abstract}

Kata kunci: dengue, ensefalopati, anak

\footnotetext{
Alamat korespondensi:

Dr. Novie Homenta Rampengan, Sp.A. Bagian Ilmu Kesehatan Anak FK UNSRAT/RSUP Prof. R.D. Kandou Manado. Jl. Raya Tanawangko, Manado 95263, Telp 0431-821652; Fax. 0431-859091. E-mail: novierampengan@yahoo.com
}

I nfeksi dengue adalah penyakit infeksi virus yang paling cepat menyebar di dunia dengan penyebaran melalui gigitan nyamuk. Dalam waktu limapuluh tahun terakhir, insiden infeksi dengue meningkat tigapuluh kali dengan peningkatan luas geografi ke negara-negara baru dan terjadi 
penyebaran infeksi virus dengue dari daerah perkotaan ke pedesaan. ${ }^{1}$ Di Indonesia angka kesakitan demam berdarah dengue (DBD) terus meningkat dari 0,05 di tahun 1968 menjadi 35,19/100.000 penduduk pada tahun $1998,{ }^{1,2}$ namun angka kematian menurun dari $41,3 \%$ di tahun 1968 menjadi 0,86\% pada tahun $2008 .{ }^{3}$ Infeksi virus dengue pada manusia mengakibatkan spektrum manifestasi klinis yang bervariasi antara penyakit paling ringan (mild undifferentiated febrile illness), demam dengue (DD), DBD sampai DBD disertai syok $($ sindrom syok dengue $=\mathrm{SSD}) .{ }^{4}$

Sejak tahun 1976, kasus dengue dihubungkan dengan keterlibatan beberapa organ vital yang mengarah ke manifestasi yang tidak lazim (unusual) atau yang tidak normal (atypical), ${ }^{5}$ dan sering berakibat fatal. Kalayanarooj dan Nimmannitya ${ }^{6}$ tahun 2004 mengklasifikasikan unusual manifestation infeksi virus dengue berupa keterlibatan susunan saraf pusat (SSP), gagal fungsi hati, gagal fungsi ginjal, infeksi ganda dan kondisi yang memperberat.

Pengamatan terbaru menunjukkan bahwa profil klinis DBD berubah dan bahwa manifestasi neurologis lebih sering dilaporkan. Insiden yang tepat berbagai komplikasi neurologis tidak pasti. Dilaporkan insiden ensefalopati yang merupakan manifestasi neurologi paling sering infeksi virus dengue didapatkan angkanya bervariasi dari $0,5-20,9 \% \%^{7-10}$ Laporan tahun 2003-2006 dari Uttar Pradesh, India mendapatkan $118 / 563$ (20,9\%) dengan acute febrile ensefalopati (AFE) dan acute undifferentiated febrile illness (AUFI) positif antibodi dengue. ${ }^{11}$ Selain itu terdapat laporan pergeseran usia pasien infeksi virus dengue ke usia yang lebih tua, sedangkan ensefalopati dengue laporannya masih terbatas.

Cam $\mathrm{dkk}^{7}$ mendapatkan semua pasien ensefalopati dengue yang hidup sembuh sempurna, tetapi berbeda dengan studi oleh Misra dkk, ${ }^{12}$ Kamath dkk, ${ }^{13}$ Kumar $\mathrm{dkk}^{14}$ yang melaporkan gejala sisa dalam studi mereka. Perbedaan mengenai insiden, usia, dan gejala sisa mendorong penulis melakukan penelitian ensefalopati dengue di RSCM, Jakarta.

\section{Metode}

Studi deskriptif retrospektif ${ }^{15}$ dilakukan di RSCM, sebuah RS rujukan tertier di Jakarta. Dilakukan penelusuran data rekam medik pasienensefalopati dengue dengan kriteria inklusi yaitu berusia lebih dari
1 bulan sampai 18 tahun yang dirawat di Departemen Anak RSCM pada tahun 2006-2010 dengan diagnosis akhir ensefalopati dengue yang dikonfirmasi dengan pemeriksaan IgM dan IgG anti dengue. Adapun kriteria eksklusi apabila rekam medis pasien hilang/ tidak lengkap. Pengambilan sampel dilakukan dengan cara total sampling. ${ }^{16}$

Diagnosis ensefalopati dengue berdasarkan diagnosis klinis DBD menurut kriteria WHO (1997) dengan keterlibatan susunan saraf pusat terdiri dari onset mendadak hiperpireksia, perubahan kesadaran sementara (gelisah, iritabel atau koma), nyeri kepala, muntah, dengan atau tanpa kejang, serta profil cairan serebrospinal (CSS) normal. ${ }^{2,4}$ Status gizi anak dinilai dengan mengukur berat badan (BB) dan tinggi badan (TB) dan interpretasi status gizi berdasarkan BB di bagi TB menurut WHO 2000. ${ }^{17}$ Keterlibatan fungsi hati yang berat jika terdapat peningkatan serum transaminase lima kali di atas nilai normal. ${ }^{18}$

Data dicatat dalam formulir yang telah disediakan kemudian dipindah-rekamkan dalam bentuk disket. Dicatat data demografi, manifestasi klinis, laboratorium, dan luaran akhir pasien dengan ensefalopati dengue. Data dianalisis dengan menggunakan Statistical Package Software versi 17 (SPSS 17). Data deskriptif disajikan secara tekstular dan tabular dalam bentuk frekuensi.

\section{Hasil}

Pencatatan data rekam medik selama tahun 20062010 terdapat 717 pasien dengan infeksi virus dengue, dan 34 pasien di antaranya menderita ensefalopati dengue. Namun dari penelusuran data di rekam medik hanya didapatkan 20 buah rekam medik, sehingga data yang diolah untukinsiden ensefalopati dengue di RSUPNCM selama tahun 2006-2010 sebesar 20/717 (2,8\%) pasien. Karakteristik demografi pasien ensefalopati dengue tertera pada Tabel 1.

Pasien terbanyak berusia 2-5 tahun (8 pasien) diikuti usia $>10$ tahun ( 7 pasien) dengan rerata usia pasien 6,6 tahun. Perbandingan laki-laki dan perempuan 1:1. Gizi kurang terdapat pada 15 pasien. Umumnya pasien datang dengan rujukan (17 pasien). Terdapat faktor-faktor yang memperberat yaitu thalasemia, HIV, tuberkolosis paru dan systemic inflammatory response syndrome (SIRS) masing-masing pada satu pasien. Diagnosis SIRS berdasarkan klinis, leukositosis $\left(24.600 / \mathrm{mm}^{3}\right)$, trombositopenia, hipotermi, dan 
Tabel 1. Karakteristik demografi pasien ensefalopati dengue

\begin{tabular}{|c|c|}
\hline Karakteristik & Jumlah \\
\hline \multicolumn{2}{|l|}{ Jenis kelamin } \\
\hline Laki-laki & 10 \\
\hline Perempuan & 10 \\
\hline \multicolumn{2}{|l|}{ Umur (tahun) } \\
\hline$<2$ & 2 \\
\hline $2-5$ & 8 \\
\hline $6-10$ & 3 \\
\hline$>10$ & 7 \\
\hline \multirow{2}{*}{ Rerata (SB) } & 6,6 \\
\hline & ( 8 bulan- 16 tahun) \\
\hline \multicolumn{2}{|l|}{ Status nutrisi } \\
\hline Gizi kurang & 14 \\
\hline Gizi baik & 5 \\
\hline Gizi lebih & 1 \\
\hline \multicolumn{2}{|l|}{ Asal pasien } \\
\hline Datang sendiri & 3 \\
\hline Rujukan & 17 \\
\hline \multicolumn{2}{|c|}{ Penyakit lain yang memperberat } \\
\hline Thalasemia & 1 \\
\hline HIV & 1 \\
\hline TB paru & 1 \\
\hline SIRS & 1 \\
\hline Tidak ada & 16 \\
\hline \multicolumn{2}{|l|}{ Derajat infeksi dengue } \\
\hline DBD derajat I & 1 \\
\hline DBD derajat II & 6 \\
\hline DBD derajat III & 5 \\
\hline DBD derajat IV & 8 \\
\hline
\end{tabular}

anemia. Juga terdapat tiga pasien dengan peningkatan marker infeksi $C$-reactive protein atau prokalsitonin (CRP/PCT) namun kurang ditunjang oleh keadaan klinis pasien. Dilakukan biakan darah dan urin pada lima pasien namun tidak tercantum hasilnya di rekam medik. Derajat infeksi dengue terbanyak DBD derajat IV pada delapan pasien diikuti DBD derajat II pada enam pasien.

Manifestasi klinis pasien ensefalopati dengue tertera pada Tabel 2. Semua pasien mengalami demam dengan rerata lama demam 4,6 hari (3-6) hari. Nyeri kepala (5 pasien), muntah (7 pasien), diare (3 pasien), kejang (8 pasien), hepatomegali (15 pasien), defisit neurologi (5 pasien). Perdarahan saluran cerna (12 pasien) yang bersamaan dengan terjadinya epistaksis (3 pasien) dan petekie (5 pasien) serta hanya terjadi petekie tampak pada 4 pasien. Penurunan kesadaran terbanyak didapat pada hari ke-4 sakit (9 pasien) dengan rerata penurunan kesadaran hari sakit ke 4,3 (2-8) hari dan rerata lama penurunan kesadaran 2,5 hari (1-6) hari. Tingkat kesadaran pasien ensefalopati dengue didapatkan apatis (10 pasien), somnolen (8 pasien) dan masing-masing 1 pasien mengalami stupor dan koma. Skor Glasgow Coma Score (GCS) pada waktu masuk rumah sakit menunjukkan rerata 10 (3-13).

Hasil laboratorium dan radiologi pasien ensefalopati dengue tertera pada Tabel 3. Pemeriksaan darah menunjukkan trombositopenia dengan rerata 76,250/

Tabel 2. Manifestasi klinis pasien ensefalopati dengue \begin{tabular}{lc}
$(\mathrm{n}=20)$ & \\
\hline Manifestasi klinis & Jumlah \\
\hline Demam & 20 \\
Lama demam, rerata (SB) & $4,6(2-6)$ hari \\
Nyeri kepala & 5 \\
Muntah & 7 \\
Diare & 3 \\
Kejang & 8 \\
Hepatomegali & 15 \\
Defisit neurologi & 5 \\
Perdarahan saluran cerna & 12 \\
Penurunan kesadaran (hari sakit), & \\
rerata (SB) & $4,3(2-8)$ \\
Lama penurunan kesadaran, rerata & \\
(SB) & $2,5(1-6)$ \\
\hline
\end{tabular}

Tabel 3. Hasil laboratorium dan pemeriksaan radiologi pada ensefalopati dengue

\begin{tabular}{lc}
\hline Laboratorium dan Radiologi & Rerata (SB) \\
\hline $\mathrm{Hb}(\mathrm{g} / \mathrm{dL}) ; \mathrm{n}=20$ & $13,1(7,6-16,1)$ \\
$\mathrm{Ht}($ vol \%); $\mathrm{n}=20$ & $40,3(22-47)$ \\
Lekosit (/uL); $\mathrm{n}=20$ & 8815 \\
& $(1.700-24.600)$ \\
Trombosit (/uL); $\mathrm{n}=20$ & 76.250 \\
& $(10.000-225.000)$ \\
Natrium (meq/L); $\mathrm{n}=19$ & $131,6(122-142)$ \\
Kalium (meq/L); $\mathrm{n}=19$ & $4,1(2,5-5,8)$ \\
Kalsium (meq/L); $=4$ & $7,6(6,9-8,5)$ \\
AGD (Hipoksemia) & 4 pasien \\
Amoniak; $\mathrm{n}=1$ & 271 \\
SGOT/AST (mg/dl); $=20$ & $2347(98-20754)$ \\
SGPT/ALT (mg/dl); $=20$ & $630(23-4031)$ \\
PT (detik); $\mathrm{n}=13$ & $22,4 "(10,3-91,8)$ \\
APTT (detik); $\mathrm{n}=13$ & $86,2 "(40,4-190)$ \\
Gambaran radiologi efusi pleura, n & 15 \\
IgM IgG anti dengue & \\
Infeksi primer, $\mathrm{n}$ & 2 \\
Infeksi sekunder, $\mathrm{n}$ & 18 \\
\hline
\end{tabular}


uL. Didapatkan hiponatremia (natrium $<135 \mathrm{mEq} / \mathrm{L}$ ) pada 15 pasien, hipokalemia (kalium $<3,5 \mathrm{mEq} / \mathrm{L}$ ) pada 2 pasien dan hipokalsemia ditemukan pada 3 pasien. Di antara 15, pasien 8 pasien mengalami hiponatremia berat (natrium $<130 \mathrm{mEq} / \mathrm{L}$ ). Terdapat satu pasien dengan peningkatan amoniak dengan tersangka sindrom Reye. Peningkatan SGOT/AST $\geq 100 \mathrm{mg} /$ dl ditemukan pada 19 pasien, 9 pasien di antaranya mempunyai kadar SGOT/AST $\geq 400 \mathrm{mg} / \mathrm{dl}$ dengan rerata $2347 \mathrm{mg} / \mathrm{dl}$. Terdapat peningkatan SGPT/ALT $\geq 100 \mathrm{mg} / \mathrm{dl}$ pada 11 pasien dengan rerata $630 \mathrm{mg} /$ dl, pemanjangan Protrombin time (PT) dengan rerata 22,4 detik dan pemanjangan aPTT dengan rerata 86,2 detik. Dari pemeriksaan foto radiologi dada didapatkan efusi pleura pada 15 pasien. Pemeriksaan serologi IgM \& IgG antidengue menunjukkan 2 pasien mengalami infeksi primer dan 18 pasien dengan infeksi sekunder. Pungsi lumbal (LP) hanya dilakukan pada 4 pasien dengan dugaan ensefalitis, dengan hasil dalam batas normal, sedangkan pada 16 pasien tidak dilakukan LP karena kesadaran pasien telah membaik.

Pengobatan yang didapat pasien ensefalopati dengue tertera pada Tabel 4. Antimikroba diberikan pada 16 pasien. Umumnya pasien mendapat sefotaksim (14 pasien) dan masing-masing 1 pasien mendapat seftriakson dan sefoperazon, dengan rerata penggunaan antibiotik 4,4 (1-9) hari. Kortikosteroid diberikan kepada 5 pasien dengan rerata penggunaan 3,2 (2-6) hari, sedangkan manitol diberikan pada 5 pasien dan tidak ada pasien yang diberikan diamox. Jenis cairan yang diberikan 10 pasien mendapat ringer asetat (RA), 8 pasien ringer laktat (RL) sedangkan masing-masing 1 pasien mendapat KAEN 1B (glukosa 5\%: $\mathrm{Nacl}=$ 3:1-kel) dan 3A (glukosa 5\%: $\mathrm{Nacl}=3: 1$ ). Terdapat 13 pasien yang mendapat koloid yaitu 10 pasien mendapat gelafusin, 2 pasien mendapat hemacell dan 1 pasien mendapat larutan HAES.

Tabel 4. Pengobatan yang didapat pasien ensefalopati dengue

\begin{tabular}{ll}
\hline Pengobatan & Jumlah \\
\hline Antimikroba & \\
Seftriakson & 1 \\
Sefotaksim & 14 \\
Sefoperazon & 1 \\
Tanpa antibiotik & 4 \\
Rerata penggunaan antibiotik (SB), hari & $4,4(1-9)$ \\
Kortikosteroid (n=5), hari & \\
$\quad$ Rerata penggunaan (SB) & $3,2(2-6)$ \\
\hline
\end{tabular}

Luaran akhir pasien ensefalopati dengue tertera pada Tabel 4. Umumnya pasien pulang dalam keadaan hidup (19 pasien), namun terdapat 1 pasien yang meninggal selama perawatan dan 3 pasien pulang dengan gejala sisa berupa slurred speech, aphasia dan tetraparesis. Rerata lama rawat pasien 6,1 (2-14) hari.

Didapatkan 4 pasien disertai penyakit lain sebagai faktor pemberat. Kasus pertama pada anak perempuan usia 9 tahun dengan HIV. Pasien juga mengalami gizi kurang dan mengalami infeksi, kadar prokalsitonin 7,4 $\mathrm{ng} / \mathrm{ml}$. Keadaan klinis pasien mengalami perbaikan setelah dirawat selama 14 hari dan mendapat antibiotik sefoperazon 7 hari. Kasus kedua anak laki-laki usia 4,5 tahun dengan thalasemia mayor, mengalami kejang, dan penurunan kesadaran pada hari ke-5 sakit. Didapatkan peningkatan refleks fisiologis dan klonus, alkalosis respiratorik, hiponatremia $(125 \mathrm{meq} / \mathrm{L})$, efusi pleura pada foto toraks, pemeriksaan LP normal, serologi anti dengue kesan infeksi primer, SGOT $199 \mathrm{mg} / \mathrm{dl}$, SGPT $67 \mathrm{mg} / \mathrm{dl}$, pemanjangan PT dan aPTT 1,5 kali. Pasien mengalami penurunan kesadaran selama tiga hari namun membaik setelah mendapat perawatan suportif selama lima hari. Kasus ketiga pada anak perempuan usia dua tahun. Saat masuk perawatan kaki tangan teraba dingin sejak 4 jam yang lalu, dijumpai penurunan kesadaran, perdarahan saluran cerna dan riwayat demam 4 hari. Laboratorium didapatkan infeksi sekunder dengue, leukositosis $(24.600 / \mathrm{ul})$ namun tanpa demam, hiponatremia $(128 \mathrm{meq} / \mathrm{L})$, hipokalsemia (6,9 meq/L), SGOT $272 \mathrm{mg} / \mathrm{dl}$, SGPT $57 \mathrm{mg} / \mathrm{dl}$. Pasien didiagnosis dengan ensefalopati dengue dengan SIRS. Pasien mengalami penurunan kesadaran selama empat hari namun membaik setelah dirawat selama 8 hari, mendapatkan sefotaksim selama lima hari dan perawatan suportif. Kasus keempat seorang anak laki-laki usia 16 tahun dengan penurunan kesadaran pada hari kedua. Pasien sementara mendapat obat anti tuberkolosis OAT bulan ke-9. Pasien kejang saat masuk perawatan, tidak ada hepatomegali, pemeriksaan LP didapatkan peningkatan sel neutrofil

Tabel 5. Luaran akhir pasien ensefalopati dengue $(n=20)$

\begin{tabular}{lc}
\hline Luaran akhir & Jumlah \\
\hline Hidup tanpa gejala sisa & 16 \\
Hidup dengan gejala sisa & 3 \\
Meninggal & 1 \\
Rerata lama rawat, hari, n (SB) & $6,1(2-14)$ \\
\hline
\end{tabular}


segmen, peningkatan hematokrit $>20 \%$, efusi pleura pada foto toraks, IgM\&IgG anti dengue positif, serta perdarahan saluran cerna. Dalam perawatan pasien mengalami penurunan kesadaran selama dua hari tanpa syok, mendapat sefotaksim dan dipulangkan setelah dirawat selama tujuh hari.

Selain itu juga dijumpai tiga kasus dengan gejala sisa. Kasus pertama pada anak laki-laki, 12 tahun, dirawat selama tiga hari di rumah sakit lain dengan penurunan kesadaran sebelum dirujuk ke RSCM pada hari keempat. Pasien dirawat dengan ensefalopati dengue dan diare akut tanpa dehidrasi. Keadaan klinis pasien membaik setelah dirawat selama empat hari namun mengalami slurred speech yang belum membaik saat tindak lanjut pada empat hari di rumah. Kasus kedua anak laki-laki, 16 tahun, rujukan dari rumah sakit lain dengan penurunan kesadaran dan sementara mendapat pengobatan anti tuberkolosis. Didapatkan paresis N. kranialis VII perifer kiri, efusi pleura positif, hemokonsentrasi $>20 \%$, SGOT $1671 \mathrm{mg} / \mathrm{dl}$, SGPT $408 \mathrm{mg} / \mathrm{dl}$, dan dijumpai infeksi sekunder dengue pada pemeriksaan uji patologis. Pasien mengalami perbaikan keadaan klinis setelah dirawat selama delapan hari dengan mendapat sefotaksim selama lima hari dan deksametason selama empat hari namun mengalami afasia selama perawatan. Kasus ketiga seorang anak laki-laki, 4 tahun masuk rumah sakit dengan penurunan kesadaran dan DBD derajat IV dengan syok berulang. Terdapat hiponatremia (127 meq/L), hipoalbuminemia, SGOT 1168 mg/dl, SGPT 260 $\mathrm{mg} / \mathrm{dl}$, pemanjangan PT dan aPTT, dan mengalami infeksi sekunder dengue. Pasien dirawat selama enam hari dan mendapat sefotaksim dua hari, namun selama perawatan pasien mengalami tetraparesis yang menetap saat tindak lanjut setelah satu minggu di rumah.

Terdapat satu kasus yang meninggal. Pasien dirawat selama empat hari di rumah sakit lain, pada hari rawat ketiga mengalami penurunan kesadaran dan keesokan harinya dirujuk ke RSCM dalam keadaan syok. Hasil laboratorium prokalsitonin $5,9 \mathrm{ng} / \mathrm{ml}$, SGOT/AST $20754 \mathrm{mg} / \mathrm{dl}$, SGPT/ALT $4031 \mathrm{mg} / \mathrm{dl}$, IgM\&IgG dengue positif. Pasien meninggal akibat koagulasi intravaskular diseminata (KID) dan sepsis.

\section{Pembahasan}

Virus dengue merupakan famili Flaviviridae yang dapat menyebabkan ensefalopati. Insidens dengue ensefalopa- ti di India $20,9 \%{ }^{11}$ sedangkan publikasi oleh Hendarto dan Hadinegoro' tahun 1992 melaporkan insiden 6,2\% di Indonesia, sedangkan studi kami menemukan insiden 2,8\%. Insiden ini lebih rendah daripada yang dilaporkan oleh Hendarto dan Hadinegoro di Indonesia. Hal ini disebabkan tidak ditemukannya data rekam medik beberapa pasien dengan ensefalopati dengue sehingga tidak diikutsertakan dari studi ini.

Ensefalopati dengue dapat disebabkan oleh syok berat akibat syok yang berkepanjangan dengan perdarahan ataupun kelebihan cairan, gangguan metabolisme seperti sindrom Reye, penggunaan obat hepatotoksik, penyakit hati yang mendasari seperti karier hepatitis B atau thalasemia, gangguan keseimbangan elektrolit seperti hiponatremia dan hipokalsemia, hipoksemia, hipoglikemia, perdarahan intrakranial, edema serebral, gagal hati, atau gagal ginjal atau keduanya. ${ }^{4,7,14,19}$ Studi kami menunjang pendapat tersebut karena terdapat perdarahan saluran cerna dan hiponatremia. Berdasarkan klasifikasi DBD menurut WHO 1997 didapatkan DBD dengan syok dan DBD tanpa syok yang mengalami ensefalopati dengue. Pada pasien dengan DBD tanpa syok, ensefalopati dengue disertai penyakit penyerta seperti diare karena mempermudah terjadinya gangguan elektrolit dan gangguan metabolisme. Studi yang dilakukan oleh Cam $\mathrm{dkk}^{7}$ mendapatkan $67 \%$ pasien DBD dengan syok.

Beberapa studi melaporkan terjadi perubahan pola distribusi usia anak dengan DBD dari sebelumnya usia 2-5 tahun ke usia yang lebih tua yang berhubungan dengan derajat beratnya infeksi dengue. Hal yang hampir sama ditemukan pada studi kami. Keadaan tersebut mencerminkan infeksi primer pada usia $<2$ tahun yang menderita DBD derajat II lebih ringan dibandingkan usia $>10$ tahun dengan infeksi sekunder serta separuh di antaranya mengalami DBD derajat IV. Ditemukan 15 pasien dengan gizi kurang empat di antaranya menderita penyakit penyerta kronik seperti HIV, tuberkulosis paru, thalasemia dan SIRS yang mempengaruhi keadaan gizi pasien.

Laporan Cam $\mathrm{dkk}^{7}$ mendemonstrasikan kemungkinan dampak neurotropik langsung virus dengue, pada studi binatang menunjukkan bahwa virus menyebabkan kerusakan sawar darah otak yang dimediasi oleh sitokin. Studi yang lain ${ }^{20}$ mengamati virus dengue pada CSS (5/6 pasien) dengan ensefalitis menunjukkan bahwa virus dapat melewati sawar darah otak dan secara langsung menginvasi otak. ${ }^{20}$ Publikasi 
studi postmortem pasien DBD yang meninggal disertai infeksi SSP menunjukkan lesi yang tidak spesifik, edema, kongesti vaskular dan perdarahan fokal. ${ }^{21,22}$ Reaksi silang antigen dapat terjadi di antara famili Flaviviridae seperti infeksi Japanese encephalitis sebelumnya dapat menyebabkan reaksi silang dengan infeksi dengue, sehingga deteksi keduanya diperlukan pada daerah kedua jenis virus ini beredar seperti di Indonesia. Namun pada studi ini tidak dilakukan pemeriksaan titer Japanese encephalitis.

Studi oleh Salomon dkk di Vietnam mendapatkan $7 / 21(33,3 \%)$ pasien dengue dengan infeksi SSP adalah infeksi primer, 13/21 $(61,9 \%)$ dengan infeksi sekunder dan 1/21 (4,8\%) tidak dapat diklasifikasikan. Studi tersebut menunjukkan infeksi sekunder lebih sering menyebabkan ensefalopati dengue daripada infeksi primer. Studi kami menunjang hal tersebut hampir seluruh pasien adalah infeksi sekunder dan hanya dua pasien dengan infeksi primer. Sedangkan Cam dkk ${ }^{7}$ mendapatkan jumlah infeksi primer sama dengan infeksi sekunder. Kami tmendapatkan dua pasien infeksi primer berusia kurang dari dua tahun.

Gejala ensefalopati yang lain tidak atau jarang menyertai DBD kecuali kejang. ${ }^{2} \mathrm{Hal}$ ini ditunjang dengan studi oleh Cam $\mathrm{dkk}^{7}$ yang mendapatkan $21 / 27(77,8 \%)$ pasien ensefalopati dengue disertai dengan kejang, sedangkan kamihanya mendapatkan $8 / 20$ pasien ensefalopati dengue dengan kejang dan lebih banyak pasien dengan perdarahan saluran cerna 12/20. Rerata waktu dari mulai sakit sampai terjadi penurunan kesadaran pada studi kami 4,3 hari (2-8 hari), hal ini berbeda dengan studi oleh Cam $\mathrm{dkk}^{7}$ yang mendapatkan 6 hari (3-9 hari) dan Kumar dkk ${ }^{14}$ yang mendapatkan 7,8 hari. Kemungkinan beberapa faktor turut berperan seperti virulensi virus dan pejamu.

Keterlibatan fungsi hati sering ditemukan selama infeksi dengue, khususnya pada pasien DBD, namun pada umumnya ringan dan tidak meningkat lebih dari lima kali nilai normal. Peningkatan enzim hati pada pasien DBD sering ditemukan dan dapat merefleksikan gangguan hati, ${ }^{23}$ sehingga menyebabkan hepatic encephalopathy seperti yang dilaporkan banyak penulis. Kami mendapatkan 19/20 pasien mengalami keterlibatan fungsi hati yang berat. Selain itu kerusakan hati dapat menyebabkan terjadinya defisiensi kompleks protrombin, 11/13 pasien. Studi Wichman $\mathrm{dkk}^{18}$ mendapatkan perdarahan saluran cerna pada $45 \%$ kasus ensefalopati dengue dengan keterlibatan hati. Hal yang sama terjadi pada studi kami, dijumpai 50\% perdarahan saluran cerna dengan keterlibatan hati.

Pada pasien dengan manifestasi tidak lazim seperti ensefalopati dengue, terdapat kemungkinan superimposed infection atau disfungsi organ multipel yang dicetuskan oleh cedera mukosa saluran cerna lewat translokasi bakteri atau respon inflamasi sistemik. ${ }^{24}$ Pada keadaan ini antibiotik dapat diberikan untuk mengobati atau mencegah keadaan tersebut. Pada studi kami, antibiotik diberikan pada 16/20 pasien dengan rerata pemakaian antibiotik 4,4 hari. Pada pasien dengan antibiotik didapatkan rerata lama rawat 7,3 hari dibandingkan dengan pasien tanpa antibiotik 5,2 hari. Deksametason diberikan pada 25\% pasien dengan rerata pemakaian 3,2 hari, rerata lama rawat 4,6 hari. Antibiotik diberikan pada kasus DBD disertai SIRS dan HIV.

Cam $\mathrm{dkk}^{7}$ yang mendapatkan angka kematian $22 \%$ dan tidak terdapat gejala sisa maksimum tujuh hari setelah rawat jalan, sedangkan Kumar dkk ${ }^{14}$ mendapatkan semua pasien ensefalopati dengue yang selamat, pada umumnya tanpa disertai gejala sisa. Namun kami mendapatkan satu kasus meninggal karena sepsis dan KID, tiga anak dengan gejala sisa tetraparesis dan gangguan bicara.

Beberapa keterbatasan pada studi kami yaitu data sekunder dari rekam medik sebagai sumber informasi seringkali tidak lengkap dan akurat.

Studi kami perlu pengamatan lebih lanjut pada pasien dengan gejala sisa dan perbaikan nutrisi.

\section{Daftar pustaka}

1. WHO. Dengue guidelines for diagnosis, treatment prevention and control. New edition 2009.

2. Sumarmo SS, Garna H, Hadinegoro SR, Satari HI, penyunting. Buku ajar infeksi \& Pediatri Tropis edisi 2. Ikatan Dokter Anak Indonesia 2008; 155-81.

3. Karyanti MR, Hadinegoro SR. Perubahan epidemiologi demam berdarah dengue di Indonesia. Sari Pediatri 2009; 10: 424-32.

4. Rampengan TH. Penyakit infeksi tropik pada anak edisi 2. Jakarta, EGC 2008; 122-49.

5. Solomon T, Dung NM, Vaughn DW, Kneen R, Thao LT, Raengsakulrach B, dkk. Neurological manifestations of dengue infection. Lancet 2000; 355: 1053-9.

6. Kalayanarooj S, Nimmannitya S. Guidelines for dengue hemorrhagic fever case management. WHO collaborating centre for case management of Dengue/ 
DHF/DSS and Queen Sirikit National Institute of Child Health (Children's Hospital). Bangkok medical publisher 2004.

7. Cam BV, Fonsmark L, Hue NB, Phuong NT, Poulsen A, Heegaard ED. Prospective case-control study of encephalopathy in children with dengue hemorrhagic fever. Am J Trop Med Hyg 2001; 65: 848-51.

8. Mendez A, Gonzalez G. Abnormal clinical manifestations of dengue hemorrhagic fever in children. Biomedica 2006;26:61-70.

9. Hendarto S, Hadinegoro SR. Dengue encephalopathy. Acta Paediatr Jpn 1992; 34:350-7.

10. Deen J, Harris E, Wills B. The WHO dengue classification and case definitions: time for a reassessment. Lancet 2006;368:170-3.

11. Tripathi P, Kumar R, Tripathi S, Tambe J, Venkatesh V. Descriptive epidemiology of dengue transmission in Uttar Pradesh. Indian Pediatr J 2008;45:315-8.

12. Misra UK. Kalita J. Spectrum of neurological manifestations of dengue in India. Dengue bulletin 2006;30:107-13.

13. Kamath S, Ranjit S. Clinical features, complications and atypical manifestations of children with severe forms of dengue hemorrhagic fever in South India. Indian J Pediatr 2006;73:889-95.

14. Kumar R, Tripathi S, Tambe J, Arora V, Srivastava A, Nag V. Dengue encephalopathy in children in Northern India: clinical features and comparison with non dengue. J of Neurological Sciences 2008:41-8.

15. Alatas H, Karyomanggolo W, Musa D, Boediarso A, Oesman I. Desain Penelitian. Dalam: Sastroasmoro S, Ismail $S$, penyunting. Dasar-dasar metodologi penelitian klinis edisi 2. Sagung Seto, Jakarta 2002.h. 79-95.
16. Sastroasmoro S. Pemilihan subyek penelitian. Dalam: Sastroasmoro $S$, Ismail $S$, penyunting. Dasar-dasar metodologi penelitian klinis edisi 2. Sagung Seto, Jakarta 2002.h. 67-77.

17. Pusponegoro H, Hadinegoro S, Firmanda D. Standard terapi ilmu kesehatan anak. Edisi I. Jakarta: IDAI, 2004.

18. Wichman O, Hongsiriwon S, Bowonwatanuwong C, Chotivanich K, Sukthana Y, Pukrittayakamee S. Risk factors and clinical features associated with severe dengue infection in adults and children during the 2001 epidemic in Chonburi, Thailand. Trop Med Int Health 2004; 9:1022-9.

19. Hadinegoro SR, Satari HI, penyunting. Demam berdarah dengue naskah lengkap pelatihan bagi pelatih dokter spesialis anak dan dokter spesialis penyakit dalam dalam tatalaksana kasus DBD. Balai Penerbit FKUI 2000.

20. Lum LC, Lam SK, Choy YS, George R, Harun F. Dengue encephalitis: a true entity? Am J Trop Med Hyg 1996;54:256-9.

21. Gulati S dan Maheswari A. Atypical manifestations of dengue. Trop Med and International Health 2007;12:1087-95.

22. Hemungkorn M, Thisyakorn U, Thisyakorn C. Dengue infection: a growing global health threat. Bio Science Trends 2007;1:90-6.

23. Souza L, Alves J, Noaueira R, dkk. Aminotransferase changes and acute hepatitis in patients with dengue fever: analysis of 1,585 cases. Braz J Infect Dis 2004;8:15663.

24. Petdachai. Hepatic dysfunction in children with dengue shock syndrome. Dengue bulletin 2005;29:112-8. 